\title{
Factors of Brand Image and Television Purchase in Kathmandu City Sajeeb Kumar Shrestha, PhD
}

Associate Professor, TU

Shanker Dev Campus

\begin{abstract}
This study attempted to measure factors of brand image and television purchase in Kathmandu City. Descriptive and causal research design was used. Primary cross-section data were collected. Structured questionnaires were administered and 200 data were obtained. Judgmental sample technique was applied. Structural Equation Modeling (SEM) tool was used to validate the model and testing causal relationships among exogenous and endogenous constructs. It was found consumer experience and after sales service were the important factors for creating brand image in the television markets. Brand image influenced television buying behavior. But celebrity endorsement and country of origin had no influence on building brand image.
\end{abstract}

Keywords: Brand image, Television purchase, SEM.

\section{Introduction}

Branding involves making different name and image to locate position in the customer's mind and attracting them. It's the customer's feeling towards the brand and effect on consumer behavior. It helps in increasing sales, expanding market share and forming brand equity (Zhang, 2015). The company's marketing strategy aim to influence customer attitude towards brand, create good brand image and motivate to actual purchase. Ultimately, it contributes on building brand equity of the product and the company (Zhang, 2015). Park, Jaworski, and Maclnnis (1986) depict creation and caring of brand image is essential for brand management. Brand image is established through functional, symbolic or experimental elements offered on products. All products are offered by some functional, symbolic or experimental elements (Park et al., 1986). 
Haedrich (1993) argue if brand image is increased, corporate image will be increased simultaneously or vice versa. Brand image means how a product, a company or a person is experienced (Haedrich, 1993). In the modern World, it becomes possible of movement of people, capital and ideas, so brand has become an important factor for differentiation and positioning (Karolina \& Insch, 2012).). Brand image has been added to marketing literature to consumer behavior since 1950s.

Keller (2003) argues that it is a set of associations organized systematically from consumer's perspectives. Brand image motivates consumers to satisfy their need, differentiates brand in the markets and increase profit for the company (Hsieh, Pan \& Setiono, 2004). Brand image makes a company's products or service better position in the market, sustainable and spreading market share (Park et al., 1986). Brand image makes the brand identifiable and keep consumers close to brand (Chernatony \& McDonald, 1998).

Celebrity endorsement in advertising is very popular and important aspect of brand marketing strategy. An individual who is publicly renown is used in an advertisement is called celebrity endorsement (McCracken, 1989). Celebrity must be related, knowledgeable and qualified to transfer meaning to the brand. Celebrity transfers meaning to the brand by his personality and popularity and so on. Credibility and match is important between celebrity and the brand. Famous celebrity is like an excellent salesperson. Company searches for familiar and contemporary face for their brand to generate brand associations in consumer's mind. Celebrity endorsement gives leverage to brand. Cohoi and Rifon (2007) argue consumer can accept the brand; switch from another to present brand, evaluate the brand and purchase the brand.

Customer experience is the cognitive and affective evaluation of the brand and the company directly or indirectly (Klaus, \& Maklan, 2013). Customer experiences in searching, evaluating and purchasing the product. Consumer experience during involvement affects consumer's expectation towards products benefits and actual benefits of the products achieved (Varki \& 
Wong, 2003). Consumer evaluates the expected and actual benefits on time (Varki \& Wong, 2003).

After sales services are provided to make consume loyal to the brand and have positive word of mouth. It includes warranty, maintenance and providing other services etc. Company gives message to the consumer that company is caring customer after the product is bought. Company's duty is not to sell the product as well as to care customers too. After sales service is important factor for customer satisfaction and customer retention.

Branding goal is to make company's brand unique in the market, capture larger market share and more profit, and allow to brand extension (Assael, 2004; Hakins, Best \& Coney, 2004; Schiffman \& Kanuk, 2010). For a consumer, product or brand is the collection of attributes that satisfy his or her needs (Assael, 2004). Consumer prefer those product attributes satisfy his needs (Assael, 2004; Hawkins, Best, \& Coney, 2004). Consumer evaluates product design, features for purchasing and use of it (Schiffman \& Kanuk, 2010). Marketers are always testing the elements of marketing mix that may affect consumer behavior significantly (Assael, 2004). These are tests are product concept tests, advertising strategy, product package and brand. Marketers undertake research to examine factors affecting consumer buying behavior. Marketers should draw the attention of consumer towards product, sell the brand and to remind (Assael, 2004).

County of origin is termed as the influence of a country's name when product or brand is chosen (Lampert \& Jaffe, 1996). It is the consumer's evaluation of the country's brands. Country of origin has influence of on consumer behavior and it is perceived as "made in image" and the "nationality bias" (Lampert \& Jaffe, 1996). Country of origin means the country of manufacturer, production or growth where the product/or brand has come from (Country-of-origin, n.d.). Country of origin has more influence on consumer perceptions when consumer is not well informed about the brand and low influence when consumer is more informed (Country-of-origin, n.d.). Country of origin is strong for durable and luxury goods and low for 
low involvement product category (Country-of-origin, n.d.). The common understanding about country of origin is least developed countries products are lower quality than developed countries (Nes \& Bilkey, 1993). Developed countries' products are superior to developing countries (Ahmed, d'Astous, \& El-Adraoui, 1994).

The markets for electronic goods are growing in fast pace like other things (Nepal is a fast growing market, 2012). Nepal's market is rising. TV sales were up by 20 percent in 2018 (Shrestha, 2018). Consumers have shown interest to purchase new and innovative technologies (Digital TV, 2018). Nepalese television markets are in tune with customers' needs (Digital TV, 2018). TV shops are introducing varieties of TV models at multiple price points to pursue wider target market (Digital TV, 2018). Sony, Samsung and LG are the major players in the Nepalese TV markets (Shrestha, 2018).

Mukherjee (2009) found celebrity endorsement influence brand image by transferring meaning to the brand. Ateke, Onwujiariri and Nnennanya (2015) confirmed Very strong relationship exists between celebrity endorsement and brand awareness in the fast-food industry in Port Harcourt. Yulianti and Tung (2013) found Consumer brand experience influence brand image. Ahmed and Snatullah (2011) found after sales service influence consumer behavior dominantly. Mingya (n.d.) confirmed product visual appearance influence brand image. Panda and Misra (20014) found COO affect brand equity directly or indirectly through brand awareness, brand loyalty and brand distinctiveness. Yanu and Fianto (2014) confirmed Brand had significant role in influencing the purchasing behavior. Literature on brand image on television markets is lacking in Nepalese context probably.

\section{Research Issues}

This study is designed to measure factors of brand image and television purchase in Kathmandu City. Research issues of this study were raised as,

- What are the factors of brand image?

- Does brand image affect television buying behavior? 


\section{Research Objectives}

These issues hence direct to the following research objectives:

- To analyze the impact of celebrity endorsement on brand image.

- To examine the impact of customer experience on brand image.

- To measure the impact of after sales service on brand image.

- To assess the impact of product design on brand image.

- To analyze the impact of country of origin on brand image.

- To investigate the impact of brand image on television purchase.

\section{Conceptual Framework}

The conceptual framework of this research is designed in figure 1.

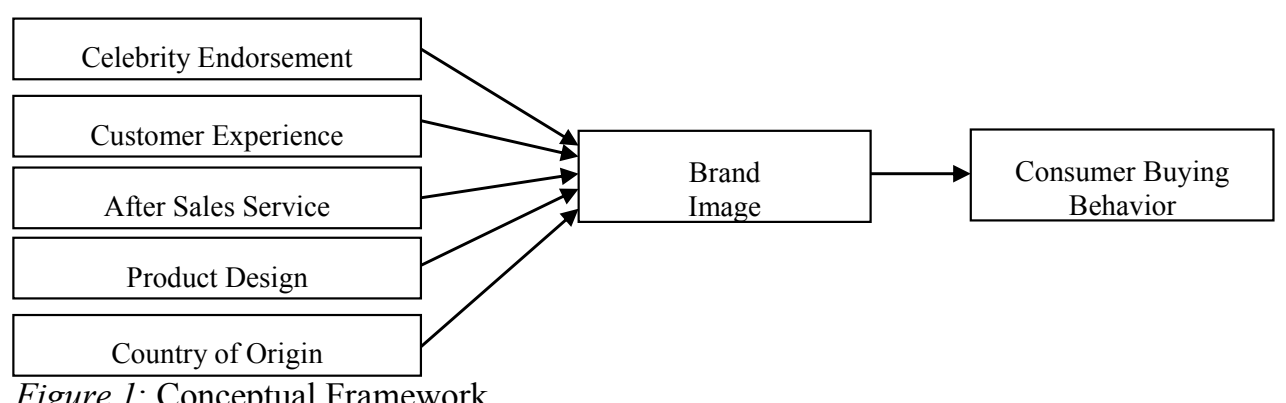

Figure 1: Conceptual Framework

\section{Hypothesis Testing}

Based on conceptual framework on figure 1, following hypotheses were proposed.

H1: Celebrity endorsement influence brand image. 
H2: Customer experience influence brand image.

H3 After sales service influence brand image.

H4: Product design influence brand image

H5: Country of origin influence brand image.

H6: Brand image influence consumer buying behavior

\section{Research Methods}

The objective of the study was to analyze factors of brand image and television buying in Kathmandu City. Descriptive and causal research design was used to achieve the objectives. Research constructs were based on literature review and conceptual framework was made.

Research subjects of the study were all the television owners in Kathmandu City. Two hundred sample respondents were contacted in the town. Kline (1998) argues 200 and more samples are considered as large sample and errors are also minimized. Eldred (1987) depicts 100 to 200 samples are enough in marketing research to achieve meaningful results. Judgmental sampling technique was applied. The respondent who has purchased the television set within one year was taken as sample of the study.

This study was cross-section study. Primary cross-sectional data were collected to achieve the objectives. Structured questionnaires were administered to collect the data. Research questionnaires were formulated on five-point Liker scale anchored by " 1 = Strongly Disagree", to " 5 = Strongly Agree".

Respondents were contacted in different locations at Kathmandu City. They were requested to fill up the questionnaires and questionnaire survey was done. Two hundred responses were collected for the study. 
Male respondents constituted 53.5 percent and female respondents constituted of 46.5 percent. Majority of the respondents i.e., 73.5 percent lied in age group of 'below 25 years'. Similarly, the age group of '25-35 years' constituted of 23.5 percent followed by age group of '35-45 years' constituted 2.5 percent. 50 percent of the respondents had bachelor degree and 44 percent had master degree. 40 percent of respondents had monthly income between Rs.25, 000 - Rs. 50,000, and 31 percent respondents had monthly income above Rs. 75,000.

Descriptive statistics was used to summarize the data. SEM was for data analysis; confirming the measurement model and testing the structural model. SPSS 20 and AMOS 20 software were used for data analysis.

\section{Results and Discussion}

Current brand of Television: Majority of the respondents were using Samsung brand television followed by LG and Sony.

Place to Purchase: Respondents wanted to purchase at company showroom, electric retailer and departmental stores. Respondents were least preferred to purchase online.

Varieties of Television: Respondents have purchased LED television set, and LCD television set.

Preferred Brand : Most preferred brand was Sony, Samsung and LG.

Preferred Size of Television: Respondents preferred 42 inch television set, followed by 32 inch.

Sources of Information: Respondents collected information mainly from Advertisement and internet sources.

Willing to spend money: Respondents tried to spend below Rs. 50,000 for purchasing television and some wanted to spend Rs. 50,000 - Rs. 75,000. 


\section{Exploratory Factor Analysis (EFA)}

Exploratory Factor Analysis (EFA) was run to pull out the non correlated constructs and refinement of the constructs from customer perspective (Hair, Anderson, Tatham \& Black, 1998). EFA is essential for CFA (Confirmatory Factor Analysis). Bartlett's test of Sphericity (Chi-square 1788.66) that is significant ( $p$-value $=0.000<0.05)$ and $\mathrm{KMO}$ value was .829 . This showed sample is enough for further processing.

Six constructs were grouped having total effect 65.54 percent of variance. Individual scale items more than 0.5 were connected into relevant constructs. Factor one was termed as brand image (BII), factor two is celebrity endorsement (CELE), factor three was consumer buying behavior (CBBB), factor four customer experience (CEE), factor five after sales service (ASS) and factor six country of origin (COOO). The final constructs resulted from exploratory factor was shown in Table 1.

Table 1

Rotated Component Matrix

\begin{tabular}{|l|r|r|c|c|c|c|}
\hline \multicolumn{7}{|c|}{ Rotated Component Matrix $^{\text {a }}$} \\
\hline & \multicolumn{7}{|c|}{ Component } \\
\cline { 2 - 7 } & 1 & 2 & 3 & 4 & 5 & 6 \\
\hline CBB1 & .800 & & & & & \\
\hline PD1 & .692 & & & & & \\
\hline BI5 & .676 & & & & & \\
\hline BI6 & .665 & & & & & \\
\hline
\end{tabular}


Factors of Brand Image and Television Purchase in Kathmandu City: Shrestha 51

\begin{tabular}{|c|c|c|c|c|c|c|}
\hline CBB2 & .662 & & & & & \\
\hline BI1 & .519 & & & & & \\
\hline CED5 & & .800 & & & & \\
\hline CED2 & & .795 & & & & \\
\hline CED3 & & .781 & & & & \\
\hline CED4 & & .675 & & & & \\
\hline CED1 & & .671 & & & & \\
\hline CBB4 & & & .652 & & & \\
\hline BI2 & & & .624 & & & \\
\hline BI4 & & & .544 & & & \\
\hline CBB5 & & & .528 & & & \\
\hline CE3 & & & & .760 & & \\
\hline CE2 & & & & .698 & & \\
\hline CE1 & & & & .561 & & \\
\hline CE5 & & & & & .694 & \\
\hline SS5 & & & & & .669 & \\
\hline SS4 & & & & & .543 & \\
\hline $\mathrm{COO} 4$ & & & & & & .788 \\
\hline
\end{tabular}




\begin{tabular}{|l|l|l|l|}
\hline COO3 & & & \\
\hline Extraction Method: Principal Component Analysis. \\
Rotation Method: Varimax with Kaiser Normalization. \\
a. Rotation converged in 8 iterations. \\
\hline
\end{tabular}

\section{Modifying Conceptual Framework}

EFA provides guidelines to modify conceptual framework. Scale times related to product design was connected to other construct and some scales item were deleted. Modifying conceptual framework was shown in Figure 2.

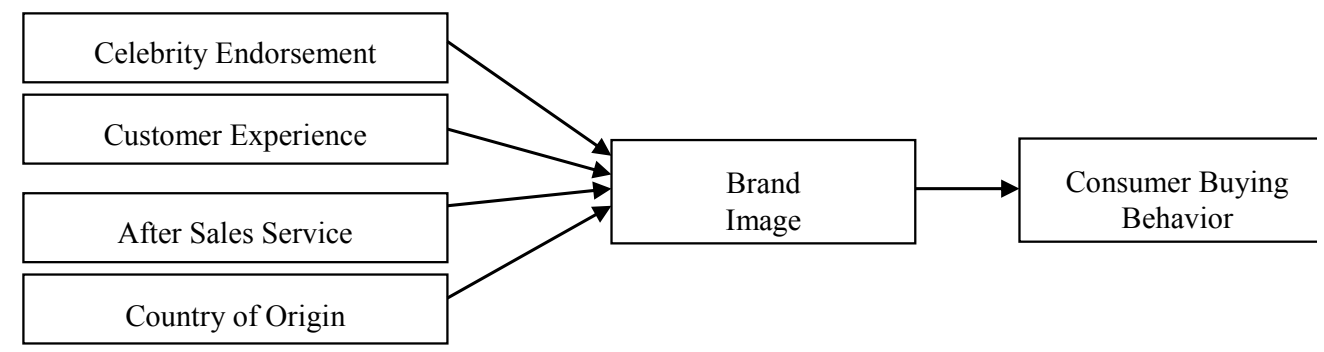

Figure 2: Modifying Conceptual Framework

\section{Modifying Hypothesis}

After EFA, hypotheses were changed as the following

H1: Celebrity endorsement influence brand image.

H2: Customer experience influence brand image.

H3 After sales service influence brand image.

H4: Country of origin influence brand image. 
H5: Brand image influence consumer buying behavior

\section{CFA (Confirmatory Factor Analysis)}

Confirmatory factor analysis was applied to test the validity of the measurement model (Anderson \& Gerbing, 1988). The measurement model provided fairly satisfactorily as $\mathrm{CMIN} / \mathrm{DF}=1.489 ; \mathrm{GFI}=.882 ; \mathrm{CFI}=.923$; RMSEA $=.050$; and RMR = .50 (Byrne, 2001; Hair et al., 1998; Joreskog \& Sorbom, 1993). This can be said that model was fairly fitted in this research. Model validation was also achieved in Nepalese television markets context (Fornell \& Larcker, 1981).

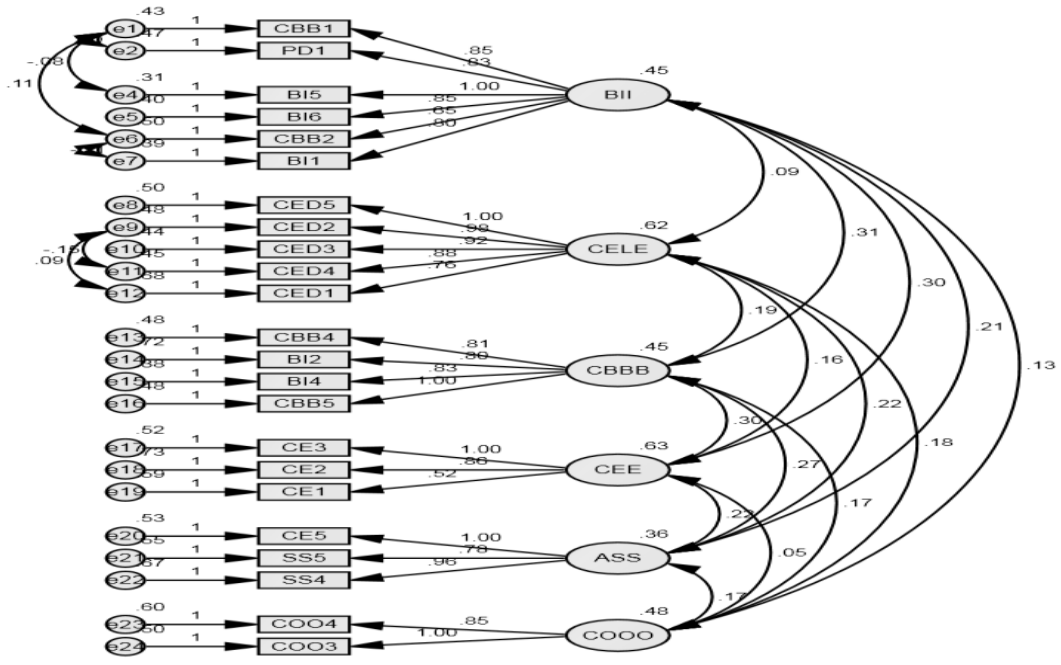

Figure 3: Measurement Model

(Note: BII - Brand Image; CELE - Celebrity Endorsement; CBBB Consumer Buying Behavior; CEE - Consumer experience; ASS - After Sales Service; COOO - Country of Origin) 


\section{SEM (Structural Equation Modeling)}

Structural equation modeling is a popular tool for testing causal relations simultaneously. It connects exogenous constructs and endogenous constructs and hypotheses are tested at once. SEM is run after CFA for testing causal relationship. CFA tests the fitness and validity of the measurement model. SEM examines the hypotheses of the structural model. Structural model is shown in Figure 4.

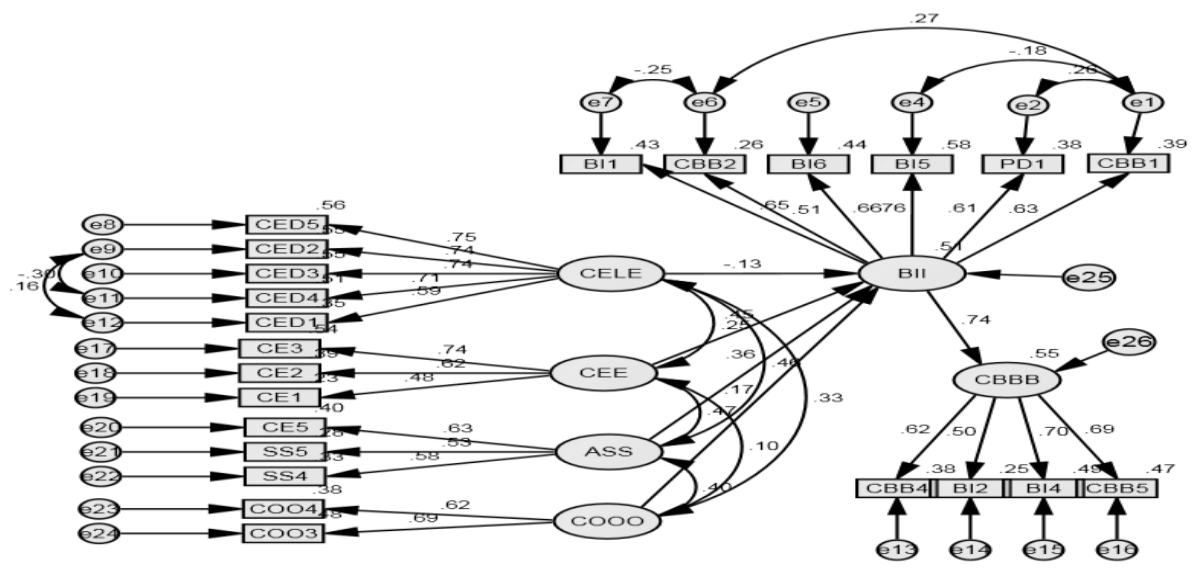

Figure 4: Structural Model

Squared multiple correlation of brand image was (.554 or 55.4\%) and consumer buying behavior (.508 or 50.8\%). This showed that the predicting capacity of the model for brand image was 55.4 percent and for consumer buying behavior was 50.8 percent. 


\section{Hypothesis Testing}

Testing of causal relation among exogenous constructs and endogenous constructs were shown in Table 2.

Table 2

Hypothesis Testing

\begin{tabular}{|c|c|c|c|c|c|c|}
\hline Hypothesis & From & To & Estimate & S. E. & $\begin{array}{c}\text { t- } \\
\text { value }\end{array}$ & Result \\
\hline H1 & $\begin{array}{c}\text { Celebrity } \\
\text { Endorsement }\end{array}$ & $\begin{array}{l}\text { Brand } \\
\text { Image }\end{array}$ & -.107 .076 & -1.398 & .162 & $\begin{array}{c}\text { Not } \\
\text { Accepted }\end{array}$ \\
\hline $\mathrm{H} 2$ & $\begin{array}{l}\text { Consumer } \\
\text { Experience }\end{array}$ & $\begin{array}{l}\text { Brand } \\
\text { Image }\end{array}$ & $.376 \quad .098$ & 3.822 & $* * *$ & Accepted \\
\hline H3 & $\begin{array}{l}\text { After Sales } \\
\text { Service }\end{array}$ & $\begin{array}{l}\text { Brand } \\
\text { Image }\end{array}$ & $.400 \quad .160$ & 2.504 & .012 & Accepted \\
\hline H4 & $\begin{array}{c}\text { Country of } \\
\text { Origin }\end{array}$ & $\begin{array}{l}\text { Brand } \\
\text { Image }\end{array}$ & .106 & 1.580 & .114 & $\begin{array}{c}\text { Not } \\
\text { Accepted }\end{array}$ \\
\hline H5 & Brand Image & $\begin{array}{c}\text { Consumer } \\
\text { Buying } \\
\text { Behavior }\end{array}$ & .742 .105 & 7.095 & $* * *$ & Accepted \\
\hline
\end{tabular}

Table 2 expressed regression coefficient of celebrity endorsement and country of origin on brand image were not significant. So, H1 and H4 were not accepted. It was viewed as celebrity endorsement and country of origin had no influence on building brand image of television set. 
Consumer experience and after sales service had an influence on brand image. These constructs were important for forming brand image of television set. Brand image influenced on consumer buying behavior.

\section{Conclusion}

The objective of the study was to analyze factors of brand image and television buying in Kathmandu City. Consumer experience, and after sales service are the major factors for developing brand image in the television markets. This is consistent with Mingya (n.d.), Yulianti and Tung (2013) and Ahmed and Sntullah (2011) that customer brand experience influences on brand image and after sales service influence brand image. Celebrity endorsement and country of origin had no effect on brand image. This result is contrast with Mukherjee (2009) that celebrity is unable to transfer meaning to the endorsed brand. This result is also contrast with Panda and Misra (2014) that brand equity is not built by country of origin. Brand image influences on consumer buying behavior. This result is consistent with Yanu and Fianto (2014) that brand has significant influence of consumer buying behavior.

Market should focus their marketing strategy on building positive brand image that will result in television buying in Kathmandu City. Sony, Samsung and LG television has opportunity to enhance brand image thereby increase consumer behavior. Kathmandu City population is growing and the number of families is also increasing. So, this will impact on purchasing television sets in the markets. 


\section{References}

Ahmed, D., \& Snatullah, A. (2011 ). After sales service and consumer buying behavior: An empirical investigation in automobile industry in Pakistan. Research, 7(3), 1-6.

Ahmed, S.A., d'Astous, A., \& El-Adraoui, M. (1994). Country-of-origin effects on purchasing managers' product perceptions. Industrial Marketing Management, 23(4), 323-332.

Anderson, J.C., \& Gerbing, D.W. (1998). Structural equation modeling in practice: A review and recommended two-step approach.

Psychological Bulletin, 103(3), 411-423.

Assael, H. (2004). Consumer behavior: A strategic approach (6 $6^{\text {th }}$ ed.). MA: Houghton Miffin Company.

Ateke, B.W., Onwujiariri, J.C., \& D.A. Nnennanya (2015). The relationship between celebrity endorsement and brand image in the Fast-food Industry in Port Harcourt, Nigeria. European Journal of Business and Management, 7(27), 177-186

Byrne, B.M. (2001). Structural equation modeling with AMOS: Basic concepts, applications and programming. Mahwah, N.J.: Lawrence Erlbaum Associates.

Chernatony, L., \& McDonald, M. (1998). Creating powerful brands (2nd ed.). Oxford, Butterworth-Heinemann.

Choi, S.M., \& Rifon, N.J. (2007). Who is the celebrity in advertising? Understanding dimensions of celebrity images. Journal of Popular Culture, 40(2), 304-325.

Eldred, G. (1987). Real estate: analysis and strategy. New York: Harper \& Row 
Fornell, C., \& Larcker, D.F. (1981). Evaluating structural equation models with unobservable variables and measurement error. Journal of Marketing Research, 18(2), 39-50.

Haedrich, G. (1993). Images and strategic corporate and marketing planning. Journal of Public Relations Research, 5(2), 83-93.

Hair, J.F. Jr., Anderson, R.E., Tatham, R.L., \& Black, W.C. (1998). Multivariate data analysis. NJ: Prentice Hall.

Hawking, D.I., Best, R.J., \& Coney, K.A. (2004). Consumer behavior: Building marketing strategy (9th ed.). Irwin: The McGraw-Hill.

Hsieh, M. H., Pan, S.L., \& Setiono, R. (2004). Product, corporate, and country-image dimensions and purchase behavior: A multicountry analysis. Journal of the Academy of Marketing Science, 32(3), 251270. doi: http://dx.doi.org/10.1177/0092070304264262

Joreskog, K., \& Sorbom, D. (1993). LISREL 8: Structural equation modeling with the IMPLIS command language. Chicago: Scientific Software International (SSI).

Karolina, J., \& Insch, A. (2012). The strategic importance of brand positioning in the place brand concept: Elements, structure and application capabilities. Journal of International Studies, 5(1), 9-19.

Keller, K.L. (2003). Strategic band management: Building, measuring and managing brand equity (2nd ed.). NJ, Jew Jersey: Prentice Hall.

Klaus, P., \& Maklan, S. (2013 ). Towards a better measure of customer experience. International Journal of Market Research, 55(2), 227246.

Kline, R.B. (1998). Principles and practice of structural equation modeling. New York: The Guilford Press. 
Lampert, S.I., \& Jaffe, E.D. (1998). A dynamic approach to country-of-origin effect. European Journal of Marketing, 32(1/2), 61078.

McCracken, G. (1989). Who is the celebrity endorser? Cultural foundations of the endorsement process. Journal of Consumer Research, 16(3), 310-321. http://dx.doi.org/10.1086/209217

Mingya, G. (n.d.). The impact of visual appearance on brand image.

Retrieved from

https://www.theseus.fi/bitstream/handle/10024/69237/Gu_Mingya.pd f? sequence $=1$

Mukherjee, D. (2009). Impact of celebrity endorsements on brand image. Retrieved from https://papers.ssrn.com/sol3/papers.cfm?abstract_id=1444814

Nepal is a fast growing market for us (2012). Retrieved from https://www.newbusinessage.com/MagazineArticles/view/1422

Nes, E. \& Bilkey, W. J. (1993). A multi-cue test of country-of-origin theory. In: N. Papadopoulos and L.A. Heslop (Eds.). Product-country images. New York: International Business.

Park, C.W., Jaworski, B.J., \& Maclnnis, D.J. (1986). Strategic brand concept - Image management. Journal of Marketing, 50, 135-145. http://dx.doi.org/10.2307/1241291

Schiffman, L.G., \& Kanuk, L.L. (2010). Consumer behavior. NJ, New Jersey, NJ: Pearson-Prentice Hall.

Shrestha, A. (2018). Television sales up by 20 percent: Traders. https://myrepublica.nagariknetwork.com/news/television-sales-up-by20-percent-traders/ 
Varki, S., \& Wong, S. (2003). Consumer involvement in relationship marketing of service. Journal of Service Research, 6(1), 83-91.

Yanu, A., \& Fianto, A. (2014). The influence of brand image on purchase behaviour through brand trust. Business Management and Strategy, $5(2), 58-76$.

Yulianti, I., \& Tung, W. (2013). The relationship among brand experience, brand image and customer satisfaction of Facebook users in Indonesia. Proceedings Book of ICEFMO. Retrieved from http://www.conscientiabeam.com/ebooks/ICEFMO-162-177.pdf

Zhang, Y. (2015). The impact of brand image on consumer behavior: A literature review. Open Journal of Business and Management, 3, 5862. Retrieved from http://www.scirp.org/pdf/OJBM_2015011615441425.pdf 